\title{
STUDIES ON THE GROWTH OF MARINE PHYTOPLANKTON
}

\author{
III. PROROCENTRUM MICANS EHRENBERG
}

\author{
By JOANNA M. KaIN \\ Marine Biological Station, Port Erin, Isle of Man \\ AND G. E. FoGG \\ Department of Botany, University College, London
}

(Text-figs. I-7)

The last of the organisms to be studied in this series was chosen as a representative of the Dinophyceae. The treatment of Prorocentrum micans Ehrenberg has been similar to that of Asterionella japonica Cleve \& Müller ex Gran (Kain \& Fogg, I958a) and Isochrysis galbana Parke (Kain \& Fogg, I958b). The present paper includes a discussion of the results for all three organisms in the light of work by previous authors.

\section{MATERIALS AND METHODS}

The strain of Prorocentrum micans used originated from the Plymouth collection (No. 97). It was freed of bacteria by the method of phototaxis (Droop, 1954). Individual cells were picked out after they had traversed six $9 \mathrm{~cm}$ Petri dishes of sterile medium. For some experiments the original unialgal culture was used and for others the bacteria-free culture.

The methods used in culturing the dinoflagellate were similar to those used for Asterionella (see Kain \& Fogg, I958a). Pyrex glass tubes $(15 \times 2.5 \mathrm{~cm})$ plugged with cotton wool were used as culture vessels and immersed in a constant temperature water bath at $20^{\circ} \mathrm{C}$ with incandescent lighting providing 5000-7000 lux.

The basic media used were Erdschreiber (Føyn, 1934), AK (Kain \& Fogg, $1958 a), \mathrm{AQ}_{\mathrm{N}}$ (based on natural sea water) and $\mathrm{AQ}_{\mathrm{A}}$ (based on artificial sea water). Medium AQ was the same as AR (Kain \& Fogg, I958a) but without sodium silicate or tris(hydroxymethyl)aminomethane ('tris'). Soil extract, at 20 or $50 \mathrm{ml}$./1., was usually added to this medium and in all later experiments cobalamin, at $0.1 \mathrm{~m} \mu \mathrm{g} / \mathrm{l}$., was included. In addition Provasoli's vitamin solution $\mathrm{S}_{3}$ (Provasoli, McLaughlin \& Droop, 1957) was added on occasion. A few experiments were made in medium BD which consisted of natural sea water enriched with nitrate, phosphate and ferric chloride at the 
same concentrations as in AK, with twelve vitamins (Table I) and $50 \mathrm{ml} . / 1$. of soil extract. Finally medium BE was developed. It was based on natural $\left(\mathrm{BE}_{\mathrm{N}}\right)$ or artificial $\left(\mathrm{BE}_{\mathrm{A}}\right)$ sea water and the usual nitrate and phosphate enrichments with the addition of the trace elements and ethylenediamine tetra-acetic acid (EDTA) as in AQ but contained also glycylglycine, at $4 \mathrm{~mm}$ and twelve vitamins (I2 V). Media were autoclaved at $15 \mathrm{lb}$./sq.in. for I min.

Growth was estimated solely by cell counts, as the large cell size and low population density prevented the use of optical density measurements. The same factors also precluded the use of the usual haemacytometer slides and at first the Utermohl technique (Lund, I95I) was used, all the cells in the sample

TABLE 1. THE CONCENTRATIONS IN THE MEDIA OF THE TWELVE VITAMINS (12V) USED

$\begin{array}{llll} & \mu \mathrm{M} & & \mu \mathrm{M} \\ \text { Thiamin } & 0.5 & \text { p-Amino benzoic acid } & 0.05 \\ \text { Riboflavine } & 0.01 & \text { Inositol } & 1.0 \\ \text { Pantothenic acid } & 0.2 & \text { Biotin } & 0.002 \\ \text { Nicotinic acid } & 0.001 & \text { Folic acid } & 0.005 \\ \text { Pyriodoxine } & 0.01 & \text { Adenine } & 0.01 \\ \text { Cobalamin } & 0.000 \mathrm{I} & \text { Guanine } & 0.01\end{array}$

being counted with an inverted microscope. Later a counting cell was constructed, suitable for use with an ordinary microscope and taking $0.5 \mathrm{ml}$. of culture. A grid of lines at $\mathrm{I} \mathrm{mm}$ intervals on an area of $\mathrm{I} \mathrm{cm}^{2}$ was drawn on a Perspex slide by a sharp knife fixed to the tube support of a microscope. The slide was moved in relation to the knife by means of a mechanical stage, the micrometer scale of which was used to determine the position of each line. The depth of the cut was controlled by the focusing mechanism of the microscope. The grid was surrounded by Perspex walls, ground to a thickness of $0.5 \mathrm{~cm}$, with four channels for the escape of excess liquid. At least 500 cells were counted to obtain an estimate of cell concentration. The distribution of cells on the grid was not quite random, there being a slightly greater concentration at the centre. Allowance was made for this if the whole grid was not scanned.

\section{Growth}

\section{EXPERIMENTS}

An example of the growth curve of Prorocentrum in bacteria-free culture is shown in Fig. I. There was sometimes a lag of about 2 days. Under optimum conditions the relative growth constant $k$ in the exponential phase was 0.3 $\log _{e}$ units/day, corresponding to a division nearly every 2 days. Growth later became slower and the maximum population reached was usually about 50 cells $/ \mathrm{mm}^{3}$ though 80 cells $/ \mathrm{mm}^{3}$ has been recorded.

Nitrogen supply

Bacteria-free Prorocentrum was grown in a series of concentrations of potassium nitrate in medium $\mathrm{BD}$ from an inoculum washed in sterile sea 
water. Cell counts were made after $2 \mathrm{I}$ days and the cell crop in each culture calculated by subtracting the mean cell concentration in the controls from that in the relevant culture. The cell crop in Fig. 2 is thus an expression of the response to the added nitrate, as distinct from that in the natural sea water or stored in the cells. Fig. 2 also shows the values for the added nitrate divided

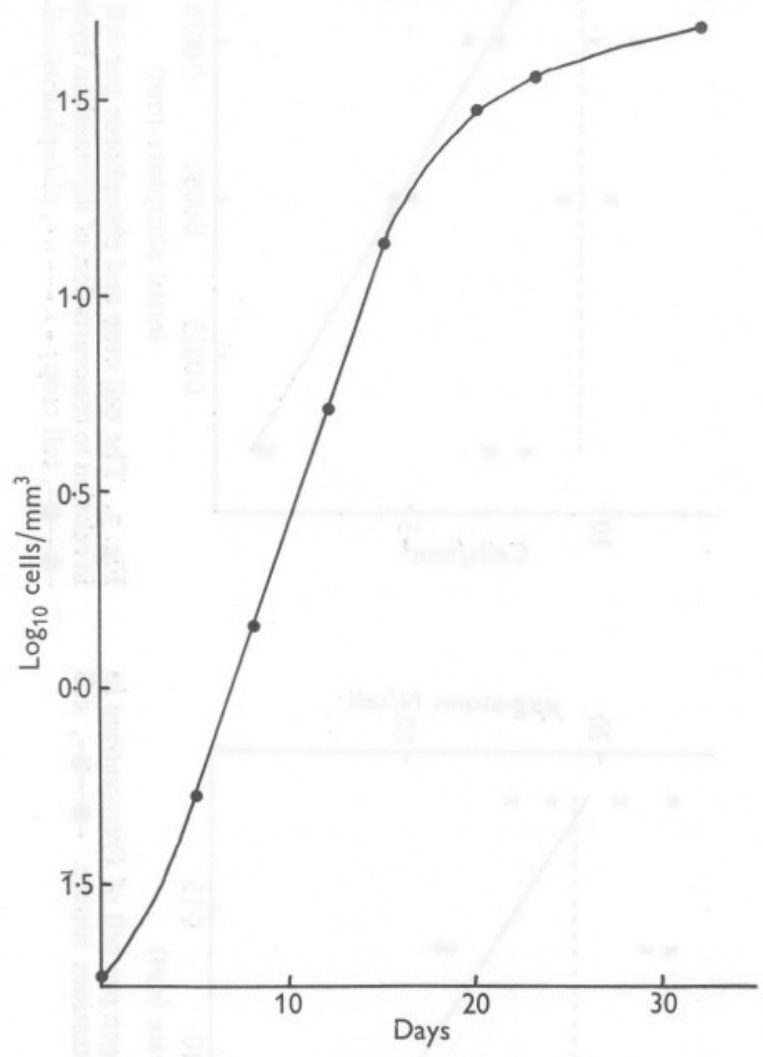

Fig. I. The mean growth curve of three bacteria-free cultures of Prorocentrum.

by the cell crop obtained from it. These do not necessarily correspond to the nitrogen contents of the cells. All except the highest ( $2 \mathrm{mM})$ concentration gave similar values, nitrate being evidently limiting, and the mean requirement was $\mathrm{I} 9 \mu \mu \mathrm{g}$-atoms $\mathrm{N} /$ cell.

\section{Phosphorus supply}

A similar experiment, also with bacteria-free cultures, was carried out in a series of concentrations of dipotassium hydrogen phosphate in medium BD and cell counts made after 29 days. The results are shown in Fig. 3. 


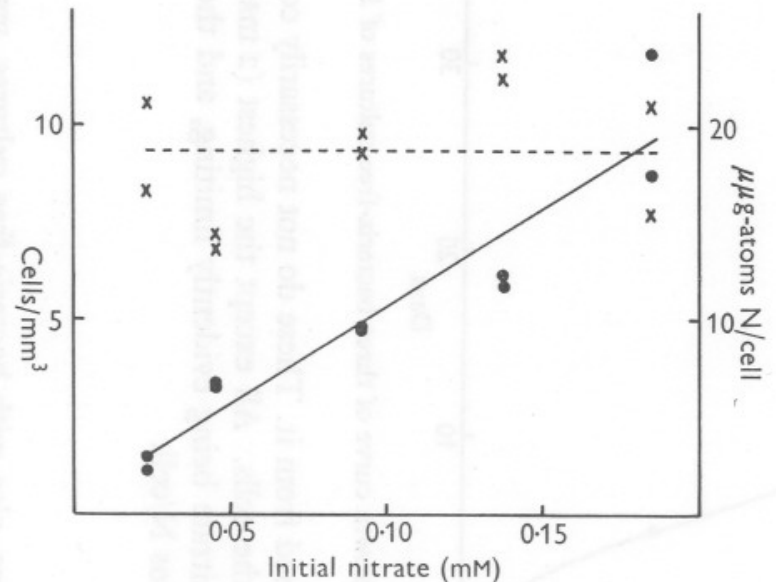

Fig. 2. The cell crop and nitrogen per cell of Prorocentrum in relation to concentration of potassium nitrate. $-\longrightarrow-$-, cell crop; $-\times---\times-$, nitrogen/cell.

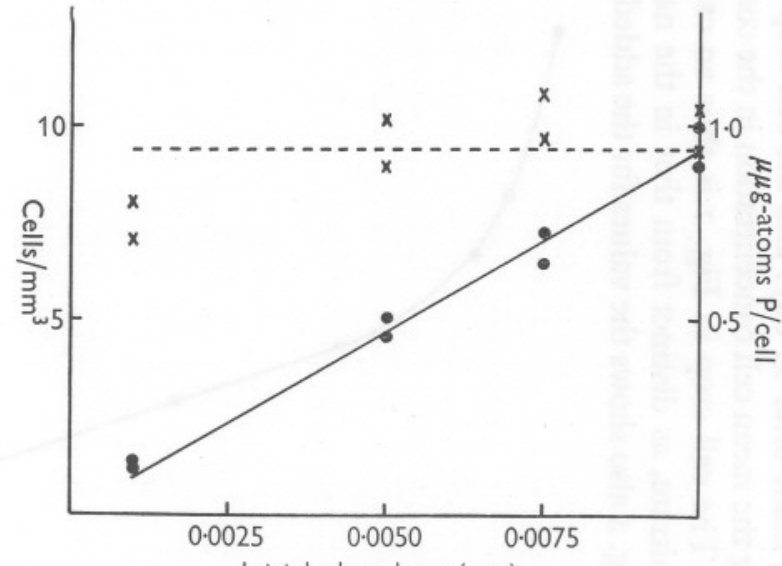

$$
\text { Initial phosphate (mM) }
$$

Fig. 3. The cell crop and phosphorus per cell of Prorocentrum in relation to concentration of dipotassium hydrogen phosphate. $\longrightarrow-\bullet$, cell crop; - $\times---\times-$-, phosphorus/cell. 
Phosphorus was evidently limiting in all but the highest concentration and the mean requirement was $0.94 \mu \mu \mathrm{g}$-atom $\mathrm{P} /$ cell.

\section{Trace elements}

In experiments carried out in Erdschreiber medium cell concentrations of the order of only Io-I 5 cells $/ \mathrm{mm}^{3}$ were obtained in uni-algal culture. It was found that this could be increased significantly by the addition of $0.01 \mathrm{~mm}$ $\mathrm{FeCl}_{3}$. Later Provasoli's trace element mixture as used for Asterionella and Isochrysis (Kain \& Fogg, I958a, b) was added to natural sea water enriched with the usual nitrate, phosphate and cobalamin concentrations and $50 \mathrm{ml} . / 1$. of soil extract. Ethylenediamine tetra-acetic acid (EDTA) was added at 0.171 and $0.342 \mathrm{~mm}$. The final cell concentrations of the uni-algal culture in

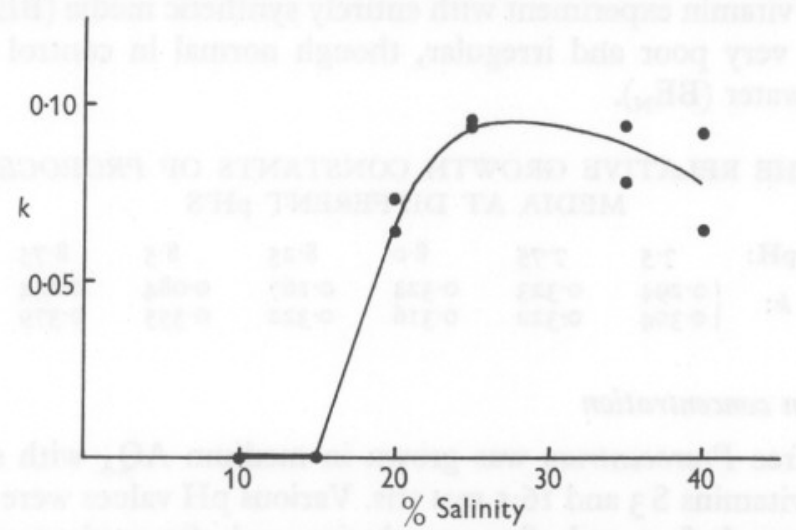

Fig. 4. The relative growth constant of Prorocentrum in media based on sea water of various salinities.

the latter $\left(23.3,23.9\right.$ and $\left.27.8 \mathrm{cells} / \mathrm{mm}^{3}\right)$ were significantly greater than in the former $\left(18.5,19.4\right.$ and 14.7 cells $\left./ \mathrm{mm}^{3}\right)$, with less EDTA. Medium AQ, which incorporates these concentrations of trace elements and EDTA at $0.342 \mathrm{mM}$, is therefore suitable for Prorocentrum.

\section{Salinity}

The uni-algal culture of Prorocentrum was grown in medium AK based on sea water of various salinities. All the cultures were inoculated with cells from $35 \%$ salinity. The relative growth constants are shown plotted against salinity in Fig. 4. A range of $20-40 \%$ salinity was tolerated.

\section{Artificial sea water}

Experiments with artificial sea water gave irregular results. When it was compared directly in medium $\mathrm{AQ}_{\mathrm{A}}$ with natural sea water in $\mathrm{AQ}_{\mathrm{N}}$, with cobalamin and soil extract added to both, growth took place in all the cultures, 
but after 46 days the cell concentrations were significantly lower in artificial sea water $\left(2.54,2.24\right.$ and 2.08 cells $\left./ \mathrm{mm}^{3}\right)$ than in natural sea water $(3.06,2.70$ and 3.24 cells $/ \mathrm{mm}^{3}$ ). On the other hand in the experiments on hydrogen-ion concentration, in which artificial sea water was used with soil extract, the relative growth constant was as high as has been observed $(k=0 \cdot 38)$. Also the experiment to determine which of the twelve vitamins was necessary (see page 43) was based on artificial sea water without soil extract and the relative growth constant was normal, from a washed inoculum. Thus there is nothing unsuitable about the substances present in the artificial sea water though a medium made up from it may lack some stimulatory factor present in variable amounts in natural sea water. That this latter is the case with Prorocentrum as well as with Asterionella (see Kain \& Fogg, 1958a) was strongly indicated by a further vitamin experiment with entirely synthetic media $\left(\mathrm{BE}_{\mathrm{A}}\right)$ in which growth was very poor and irregular, though normal in control cultures in natural sea water $\left(\mathrm{BE}_{\mathrm{N}}\right)$.

TABLE 2. THE RELATIVE GROWTH CONSTANTS OF PROROCENTRUM IN MEDIA AT DIFFERENT pH'S

\begin{tabular}{|c|c|c|c|c|c|}
\hline H: & $7 \cdot 75$ & 8.0 & 8.25 & 8.5 & 8.75 \\
\hline$\left\{\begin{array}{l}0.294 \\
0.304\end{array}\right.$ & $\begin{array}{l}0.323 \\
0.322\end{array}$ & $\begin{array}{l}0.324 \\
0.316\end{array}$ & $\begin{array}{l}0.167 \\
0.322\end{array}$ & $\begin{array}{l}0.084 \\
0.355\end{array}$ & $\begin{array}{l}0.244 \\
0.379\end{array}$ \\
\hline
\end{tabular}

\section{Hydrogen-ion concentration}

Bacteria-free Prorocentrum was grown in medium $\mathrm{AQ}_{\mathrm{A}}$ with soil extract, cobalamin, vitamins $\mathrm{S}_{3}$ and $16.5 \mathrm{~mm}$ tris. Various $\mathrm{pH}$ values were maintained by adjustments before and after autoclaving and after 5 days growth. The relative growth constants, calculated from cell counts made after 7 days, are shown in Table 2. The variable results above $\mathrm{pH} 8$ were probably due to differences in precipitation during autoclaving. Apart from this there was no apparent effect between $\mathrm{pH} 7.5$ and 8.75 .

\section{Light}

In the course of an experiment on Prorocentrum it was noted that identical cultures in separate tanks at the same temperature illuminated by fluorescent and incandescent lamps, respectively, showed markedly different growths. Those in incandescent light flourished while those in fluorescent light ceased growth after two divisions. In investigating the optimum light intensity for this organism therefore, both types of lamp were used. As the spectral composition of light from the two types is different, the energy output per unit of illumination (e.g. lux) is not the same from each. It is therefore necessary to use energy units in direct comparisons.

In two experiments at relatively low light intensities the lag time was 
measured by extrapolating the exponential growth line back to the inoculum level. The results of this are shown in Fig. $5 a$ (in incandescent light) and Fig. $5 b$ (in fluorescent light, not inhibitory on this occasion). In both there was a reduction of lag with increasing light intensity, at least up to the saturation level.

Four experiments were made with incandescent light, using lamps of different wattages, with cultures at various distances from the source. The results are combined in Fig. $6 \mathrm{a}$. The saturation level (at $20^{\circ} \mathrm{C}$ ) was at about

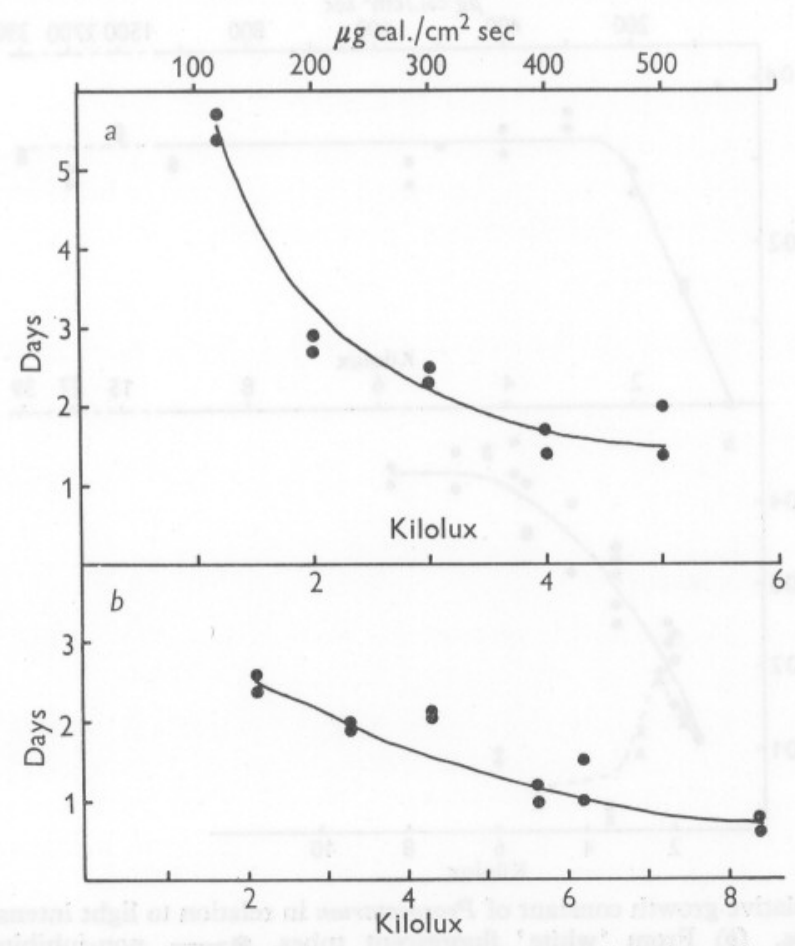

Fig. 5. The lag time of cultures of Prorocentrum in relation to light intensity. (a) From tungsten lamps. (b) From 'white' fluorescent tubes. The energy scale at the top applies to both (a) and (b).

$300 \mu \mathrm{g}-\mathrm{cal} / \mathrm{cm}^{2} \mathrm{sec}$ (or 3000 lux as indicated by a selenium photocell light metre). There was no inhibition at $3900 \mu \mathrm{g}-\mathrm{cal} / \mathrm{cm}^{2} \mathrm{sec}$ (or $39,000 \mathrm{lux}$ ), an intensity which was obtained at about $10 \mathrm{~cm}$ from a $1000 \mathrm{~W}$ bulb.

The fluorescent tubes used were 'white'. The inhibition of growth by this type of light was observed in four separate experiments, involving two different makes of lamp, with identical control cultures in incandescent illumination in which growth was normal. The relative growth constants of some of these are shown as crosses in Fig. $6 b$. Below $150 \mu \mathrm{g}-\mathrm{cal} / \mathrm{cm}^{2} \mathrm{sec}$ the growth constant increased with light energy but above this value it declined markedly. 
In one experiment (shown as circles in Fig. $6 b$ ) over the same range of energy no inhibition was observed at all, and the relative growth constant increased with light energy to saturation at about $400 \mu \mathrm{g}-\mathrm{cal} / \mathrm{cm}^{2} \mathrm{sec}$. That the saturation energy was higher than that for incandescent light may be attributed to the less suitable spectral distribution of energy in fluorescent light or, since the relative growth rate achieved was higher in the latter, to the removal of some other limiting factor. It is not known what factors cause the inhibition by this

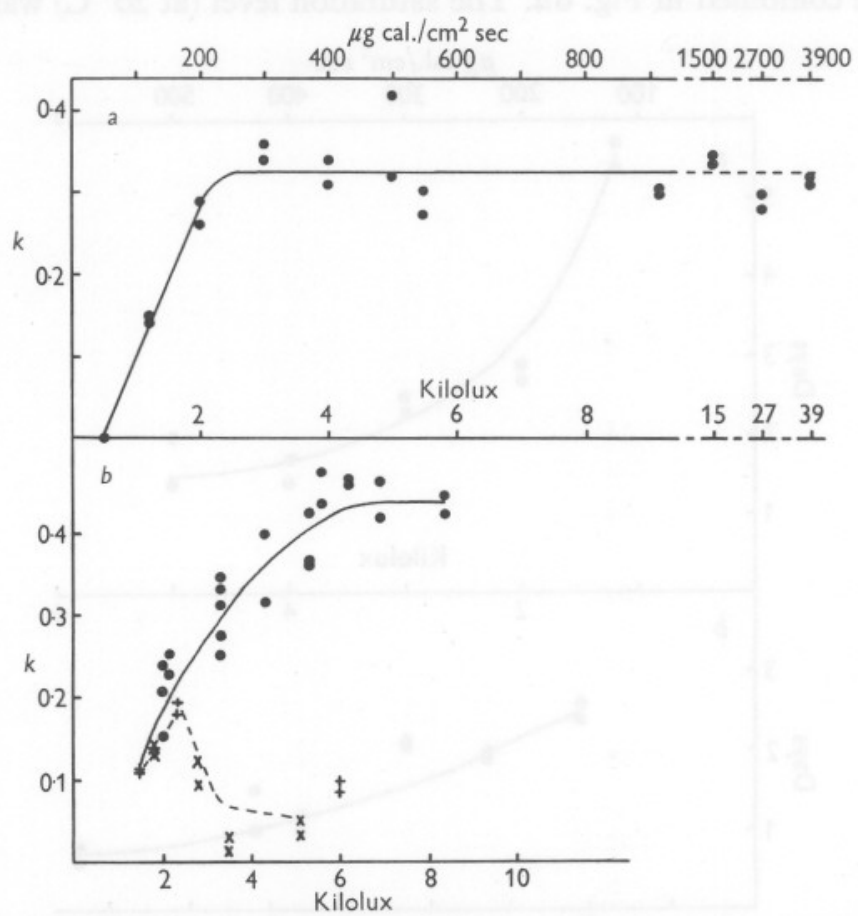

Fig. 6. The relative growth constant of Prorocentrum in relation to light intensity. (a) From tungsten lamps. (b) From 'white' fluorescent tubes. - - non-inhibitory; $\times+---$, inhibitory.

type of light. The possibilities include the medium, the physiological state of the cells and the age of the fluorescent tubes.

In investigating the cause of the inhibition it is necessary to compare the emission spectrum of this type of fluorescent lamp with that of an incandescent tungsten filament bulb. These are shown in Fig. $7 a$, where the total relative energy, represented by the area below the curves, has been made the same between 380 and $720 \mathrm{~m} \mu$. The position of the principal peak in emission in the region of least absorption by Prorocentrum (Fig. $7 b$ ) indicates the unsuitability of this type of light for photosynthesis. It is possible that the wave-band $425-445 \mathrm{~m} \mu$ could contain sufficiently more energy in fluorescent 
than incandescent light to account for the inhibition. The other possibility is that the ratio of wavelengths is in some way responsible. In this connexion it is worthy of note that the action spectrum of phototaxis of $P$. micans was found by Halldal (1958) to have its peak at about $575 \mathrm{~m} \mu$ (see Fig. 7 b), very near to the peak in emission of 'white' fluorescent light.

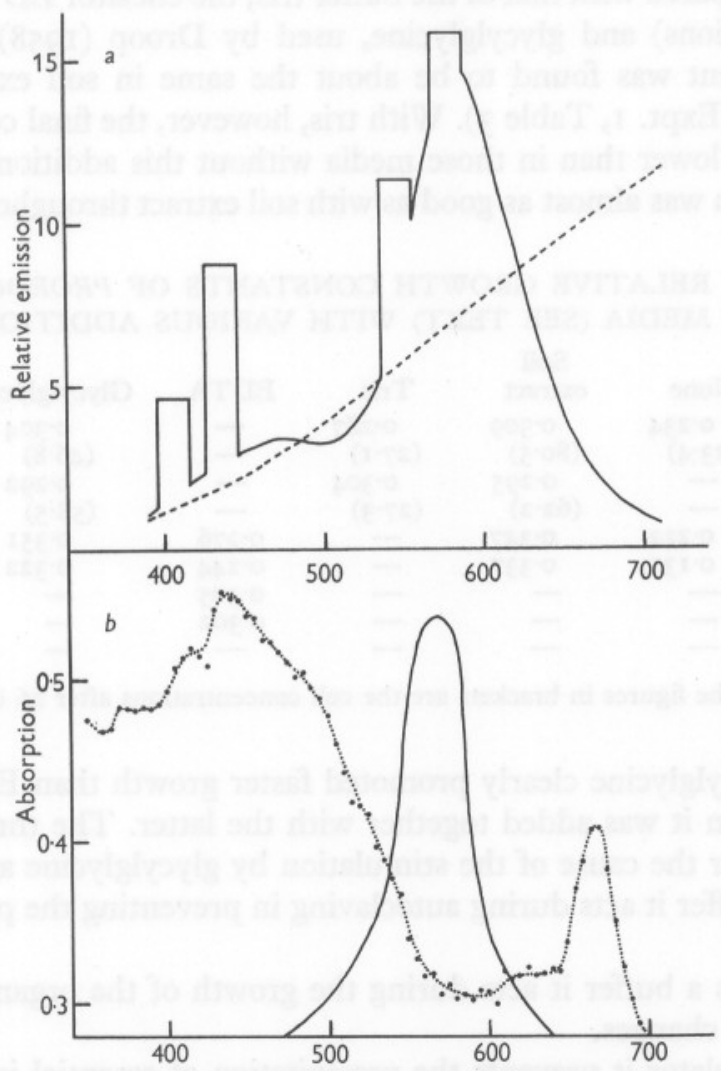

Fig. 7. (a) The emission spectra of lamps giving equal energy between 380 and $720 \mathrm{~m} \mu$. -, Ekco 'white' fluorescent tubes (by permission of Ekco-Ensign Electric Ltd.); - - -, tungsten filament lamp. (b) - , the phototaxis action spectrum of Prorocentrum micans (from Halldal, 1958$) ; \cdots \cdots$, the absorption spectrum of $P$. micans suspended in glycerol.

\section{Stimulatory substances}

In our early experiments on Prorocentrum in Erdschreiber medium it was found that soil extract was essential for good growth, especially when the culture was bacteria-free. In attempts to characterize the stimulatory factor a number of substitutes were tried. In all these experiments a mixture of twelve vitamins (see Table I) in addition to nitrate, phosphate and iron was included in the basal sea-water medium. The results, expressed in terms of 
relative growth constants and in one case as the cell concentration at the end of the experiment, are shown in Table 3. It is clear that even in the presence of the vitamins soil extract was still stimulatory. Its action cannot be attributed to its providing any of these particular substances and the likely possibilities are that it was acting as a buffer or a chelator. The effect of its addition was therefore compared with that of the buffer tris, the chelator EDTA (with trace element additions) and glycylglycine, used by Droop (1958). The relative growth constant was found to be about the same in soil extract, tris and glycylglycine (Expt. I, Table 3). With tris, however, the final cell populations attained were lower than in those media without this addition. With glycylglycine growth was almost as good as with soil extract throughout. In Expt. 2

TABLE 3. RELATIVE GROWTH CONSTANTS OF PROROCENTRUM IN MEDIA (SEE TEXT) WITH VARIOUS ADDITIONS

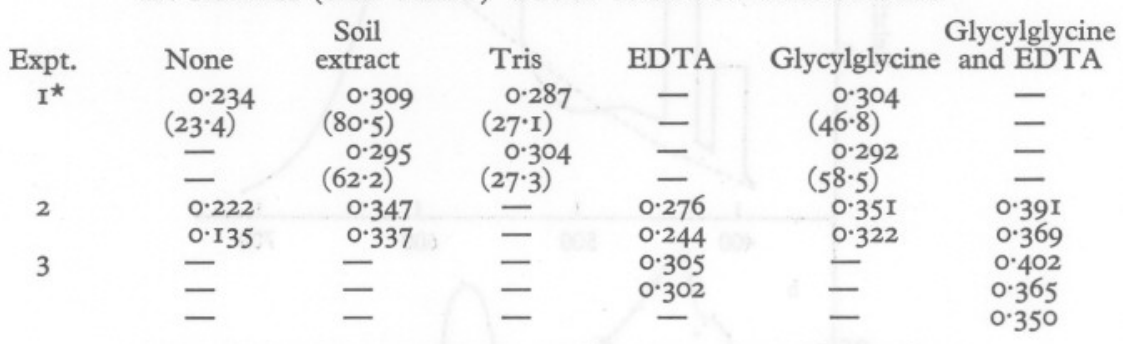

* The figures in brackets are the cell concentrations after 26 days.

(Table 3) glycylglycine clearly promoted faster growth than EDTA both by itself and when it was added together with the latter. The three most likely possibilities for the cause of the stimulation by glycylglycine are:

(I) As a buffer it acts during autoclaving in preventing the precipitation of essential ions.

(2) Again as a buffer it acts during the growth of the organism, reducing inhibitory $\mathrm{pH}$ changes.

(3) As a chelator it prevents the precipitation of essential ions or reduces the concentration of toxic ions.

If the first were the case then its superiority over EDTA would disappear if the autoclaving process were omitted. However, in Seitz-filtered media which were not autoclaved, the stimulation was still significant. In Expt. 3 (Table 3) the initial $\mathrm{pH}$ of the medium in both cases was about 6.4 and the final $\mathrm{pH}$ with EDTA alone was 8.2 while with glycylglycine it was 7.7 As the initial $\mathrm{pH}$ was the same and the final values both within the optimum range for the organism (Table 2) it is unlikely that the buffering action of glycylglycine is important in the stimulatory effect. It seems probable that it acts as a chelator, being in some way more suitable than either tris or EDTA. 


\section{Vitamins}

Droop (1957) has already reported the requirement for cobalamin of the organism. In order to determine which of the twelve vitamins used in the current media were necessary, thirteen duplicate cultures were grown in medium $\mathrm{BE}_{\mathrm{A}}$, in each one of twelve of which a different vitamin was omitted. The inoculum was washed and the concentration of the previous medium was $0.06 \%$. Cotton-wool plugs were not used. The cell concentrations after II and 18 days are shown in Table 4 . The requirement for cobalamin was confirmed by the low and stationary (after I I days) cell concentration in its absence. Growth was also less in the absence of biotin. None of the other vitamins

\section{TABLE 4. THE CELL CONCENTRATIONS IN CULTURES WITH VITAMIN OMISSIONS}

\begin{tabular}{|c|c|c|c|c|}
\hline \multicolumn{5}{|c|}{$\quad\left(\right.$ Cells $\left./ \mathrm{mm}^{3}\right)$} \\
\hline & \multicolumn{2}{|c|}{ II days } & \multicolumn{2}{|c|}{ I8 days } \\
\hline No omission (i.e. with twelve vitamins) & $13 \cdot 8$ & 13.4 & $32 \cdot 9$ & $4 \cdot 2$ \\
\hline No thiamin & $I 6 \cdot 1$ & 13.5 & $33 \cdot 3$ & $7 \cdot 6$ \\
\hline No riboflavine & 15.9 & 14.0 & $31 \cdot 2$ & 24.9 \\
\hline No pantothenic acid & $14 \cdot 3$ & $6 \cdot 46$ & $24 \cdot 0$ & $15 \cdot 9$ \\
\hline No nicotinic acid & $12 \cdot 8$ & 9.44 & $25 \cdot 7$ & $23 \cdot 8$ \\
\hline ridoxine & II 6 & $12 \cdot 7$ & $23 \cdot 6$ & 30.7 \\
\hline o cobalamin & 2.68 & 3.08 & $3 \cdot 14$ & $3 \cdot 00$ \\
\hline No $p$-amino benzoic acid & I4:7 & $12 \cdot 4$ & $28 \cdot 9$ & $29 \cdot 7$ \\
\hline No inositol & $14 \cdot 3$ & $12 \cdot 8$ & $27 \cdot 8$ & $32 \cdot 3$ \\
\hline otin & $7 \cdot 95$ & $7 \cdot 69$ & $12 \cdot 0$ & 9.67 \\
\hline cid & 15.9 & 12.6 & $3 r \cdot 4$ & $28 \cdot 2$ \\
\hline 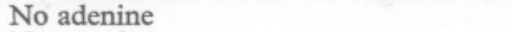 & $17 \cdot 2$ & II. 4 & $30 \cdot 8$ & $3 r \cdot 0$ \\
\hline guanine & II 7 & 15.5 & $27 \cdot 8$ & $27 \cdot 4$ \\
\hline
\end{tabular}

appear to have been necessary, though it is doubtful whether a single experiment, even using a washed inoculum, is sufficient to establish the independence of the organism from external sources of these substances.

\section{DISCUSSION}

These results obtained with Prorocentrum micans will now be considered, together with those presented in previous papers of the series (Kain \& Fogg, I $958 a, b)$ for Asterionella japonica and Isochrysis galbana.

\section{Nitrogen supply}

Nitrate has been the only source of nitrogen used in our work but appears to be the most generally suitable source for phytoplankton. In common with workers studying various other kinds of algae (see Fogg, 1959) we have been unable to demonstrate the limitation of exponential growth rate by nitrate concentration. Barker (I935) had already shown that the exponential growth 
of Prorocentrum micans is unaffected by variation in nitrate concentration between 0.016 and I6 mM. At limiting concentrations, the final yield of cell material is proportional to the amount of nitrate originally supplied (Spencer, 1954; Miller \& Fogg, 1957) and a minimum nitrogen content per cell is approached. From our results it is possible to determine the minimum nitrogen requirement per cell which is not necessarily equivalent to minimum nitrogen content per cell, since a proportion of the nitrogen assimilated may be liberated in extracellular form. Some values for the minimum nitrogen content or requirement per cell are given in Table 5. From approximate cell volumes determined from models, values for the mean nitrogen content per unit volume of protoplast have been calculated and are seen to be of the same order for the various organisms considered. Above the minimum value the

TABLE 5. MINIMUM NITROGEN CONTENT OR REQUIREMENT PER CELL OF VARIOUS ALGAE

\begin{tabular}{|c|c|c|c|c|}
\hline Species & $\begin{array}{c}\text { Cell } \\
\text { volume } \\
\mu^{3}\end{array}$ & $\begin{array}{c}\mu \mu \mathrm{g} \text {-atoms } \\
\mathrm{N} / \text { cell }\end{array}$ & $\begin{array}{l}\mu \mathrm{g} \text {-atoms } \\
\mathrm{N} / \mathrm{mm}^{3}\end{array}$ & Author \\
\hline japonica & 920 & 0.25 & 0.27 & Kain \& Fogg, $1958 a$ \\
\hline A. formosa & 1,800 & 0.4 & 0.4 & Lund, 1950 \\
\hline Isochrysis galbana & $3 I$ & 0.051 & $1 \cdot 6$ & Kain \& Fogg, I958b \\
\hline Prorocentrum micans & 17,000 & 19 & $I \cdot I$ & This paper \\
\hline Peridinium I & 3,200 & & 0.47 & Barker, I935 \\
\hline Monodus subterraneus & 120 & 0.0228 & 0.19 & Miller \& Fogg, I957 \\
\hline
\end{tabular}

nitrogen content per cell may vary greatly and it is to be expected that such variations are accompanied by considerable changes in metabolic activity and pattern (Fogg, 1959).

\section{Phosphorus supply}

Orthophosphate has been the only source of phosphorus used in our experiments and, as for nitrate, it is difficult to determine the concentrations which would limit the exponential growth rate. Ketchum (1939b) reported that variation in phosphate concentration between 0.00053 and $0.0016 \mathrm{mM}$ had no effect on the relative growth constant of Nitzschia closterium. The growth of some algae is inhibited by high phosphate concentrations of the order of $0.5 \mathrm{~mm}$ (Chu, 1943; Provasoli \& Howell, 1952). For Asterionella japonica we have found that the relative growth rate remains constant within the range 0.01 to $0.31 \mathrm{~mm}$ phosphate. The phosphorus content of algal cells may vary within wide limits according to conditions, but for a given species the minimum content is fairly constant (Ketchum, I939a; Goldberg, Walker \& Whisenand, 195I; Mackereth, 1953). Values for the minimum phosphorus requirement of various algae, determined as for minimum nitrogen requirements, are given in Table 6, from which it seems that, while the mean phosphorus requirement or content per unit volume of protoplasm may be fairly constant for the 
marine species, those for freshwater species may be an order of magnitude lower.

\section{Salinity}

Of the three organisms studied, A.japonica is the least tolerant of variations in salinity, having a well-defined optimum in relative growth rate between 30 and $35 \%$ salinity. In contrast, the relative growth rate of Isochrysis galbana is little affected by variation between $\mathrm{I}_{5}$ and $40 \%$ salinity. The results obtained for Prorocentrum micans (optimum between 25 and $40 \%$ salinity) are in reasonable agreement with those of Braarud \& Rossavik (I95I).

TABLE 6. MINIMUM PHOSPHORUS CONTENT OR REQUIREMENT PER CELL OF VARIOUS ALGAE

\begin{tabular}{|c|c|c|c|c|}
\hline Species & $\begin{array}{c}\text { Cell } \\
\text { volume } \\
\left(\mu^{3}\right)\end{array}$ & $\begin{array}{c}\mu \mu \mathrm{g} \text {-atoms } \\
\mathrm{P} / \text { cell }\end{array}$ & $\begin{array}{c}\mu \text { g-atoms } \\
\mathrm{P} / \mathrm{mm}^{3}\end{array}$ & Author \\
\hline Asterionella japonica & 920 & 0.05 & 0.05 & Goldberg et al., 195 I \\
\hline itzschia closterium & 580 & 0.0066 & 0.011 & Ketchum, 1939a \\
\hline sterionella formosa & 1,800 & 0.0018 & 0.001 & Rodhe, r948 \\
\hline & - & 0.0006 & 0.0003 & $\begin{array}{l}\text { Lund, I950 } \\
\text { Mackereth, } 1953\end{array}$ \\
\hline ochrysis galb & & $\begin{array}{l}0.002 \\
0.00007\end{array}$ & $\begin{array}{l}0.001 \\
0.03\end{array}$ & $\begin{array}{l}\text { Mackereth, I953 } \\
\text { Kain \& Fogg, I958b }\end{array}$ \\
\hline rorocentrum micans & 17,000 & $\begin{array}{l}0.00097 \\
0.94\end{array}$ & 0.055 & This paper \\
\hline Peridinium I & 3,200 & 0.159 & 0.05 & Barker, 1935 \\
\hline Monodus subterraneus & 120 & 0.00089 & 0.007 & Miller \& Fogg, I957 \\
\hline
\end{tabular}

\section{Temperature}

Previous determinations of the effects of temperature on phytoplankton organisms (Barker, I935; Ryther, I954; Spencer, 1954; Nordli, 1957) have shown the lower and upper limits for growth to be about $5^{\circ}$ and $30^{\circ} \mathrm{C}$ and the optima to be usually between $15^{\circ}$ and $27^{\circ} \mathrm{C}$. The precise values obtained in a given experiment will vary according to conditions, e.g. light intensity and the presence of bacterial contaminants may have important effects. Our results are in general agreement with those of previous workers and it seems that the optimum temperatures for the growth of the three species studied are higher than any they are likely to encounter in nature.

\section{Light intensity}

The comparison of results obtained by different workers on the effect of light intensity on algal growth is difficult. Two sets of units (of illuminance and of irradiance), which are not readily interconvertible, are in use; the geometry of the apparatus used and the density of the suspension may have effects making the actual light intensity reaching the cells considerably different from that recorded by a photometer; and the calibration of commercial photometers cannot be relied upon (Myers, 1946). Determinations of effects on photosynthesis cannot be taken as being equivalent to the effects 
on growth since saturating intensities for the former may be much higher than for the latter (Myers, 195I). Our determinations of the effect on growth gave values which are of the same order as those found in other studies on algae. The saturating intensity for Asterionella japonica, c. 4000 lux from a tungsten lamp ( $\left.400 \mu \mathrm{g}-\mathrm{cal} / \mathrm{cm}^{2} \mathrm{sec}\right)$ is about the same as those reported for various fresh-water Chlorella species, a Scenedesmus and a Chlamydomonas (Sorokin \& Krauss, 1958). That for Isochrysis galbana is lower, c. I500 lux (I50 $\mu \mathrm{g}$ $\mathrm{cal} / \mathrm{cm}^{2} \mathrm{sec}$ ), but similar values have been recorded for Chlorella pyrenoidosa (Myers, 1953). The relative growth rate of Prorocentrum micans reaches its maximum at $300-400 \mu \mathrm{g}-\mathrm{cal} / \mathrm{cm}^{2} \mathrm{sec}$. We have not observed light inhibition of the growth of either Asterionella japonica or Isochrysis galbana; the highest light intensities used being well below 20,000 lux, at which intensity inhibitory effects on the growth of Chlorophyceae become apparent (Sorokin \& Krauss, 1958). No inhibition of the growth of Prorocentrum micans was found by us in light of an intensity of $39,000 \mathrm{lux}\left(3900 \mu \mathrm{g}-\mathrm{cal} / \mathrm{cm}^{2} \mathrm{sec}\right)$ from tungsten lamps. On a number of occasions, though not invariably, we have observed inhibition at $3000 \mathrm{lux}\left(200 \mu \mathrm{g}-\mathrm{cal} / \mathrm{cm}^{2} \mathrm{sec}\right)$ from 'white' fluorescent tubes. Nordli (1957) has also recorded inhibition of the growth of dinoflagellates by relatively low intensities of light from fluorescent lamps but Haxo \& Sweeney (1955), who used light from 'white' fluorescent tubes, found 5000-8000 lux to be optimal for Gonyaulax polyedra and made no mention of inhibitory effects. Nordli (1957) attributed the more marked inhibition of Ceratium furca by continuous light from fluorescent lamps to the overstimulation of phototaxis, but further work is needed to establish this point.

\section{Hydrogen-ion concentration}

Until buffers such as tris(hydroxymethyl)aminomethane were used(Provasoli, McLaughlin \& Pintner, I954) there was difficulty in controlling the $\mathrm{pH}$ of sea-water media and information on the effect of $\mathrm{pH}$ on the growth of marine phytoplankton is correspondingly scanty. Our results support the conclusion of Bachrach \& Lucciardi (1932) that the $\mathrm{pH}$ optimum for marine diatoms is near to that of natural sea water. The lower limit of the optimum range is less than $\mathrm{pH} 7 \cdot 5$ for the three organisms studied by us. Asterionella japonica seems to be the most sensitive to alkaline conditions, an appreciable decrease in relative growth constant occurring above $\mathrm{pH} \mathrm{8.25}$, while Prorocentrum micans is the most tolerant, the maximum relative growth constant being maintained to at least $\mathrm{pH} 8.75$. Our results for $P$. micans are in good agreement with those obtained previously for this organism by Barker (1935).

\section{Other factors affecting growth}

Requirements for organic substances have now been established for many marine phytoplanktonic organisms (see the reviews by Droop, 1957 and by 
Provasoli, 1957, 1958a, b). Our failure to grow Asterionella japonica in the absence of bacteria and other pieces of evidence suggest that this organism has a requirement for one or more organic growth factors and there are also indications that it produces an autoinhibitor in the course of growth. The chemical nature of these substances is as yet entirely unknown. Prorocentrum micans, isolated by us into bacteria-free culture, appears to require cobalamin and biotin in addition to some other possible substance. Since our work was completed it has been reported that Isochrysis galbana has requirements for cobalamin and thiamin (Provasoli, 1958b).

\section{THE LARGE-SCALE CULTURE OF MARINE PHYTOPLANKTON}

The mass culture of microscopic algae is a possible means of producing feedingstuffs or organic materials for industry. While the use of sea water rather than fresh water as a medium for this has no intrinsic value it might be

\section{TABLE 7. GROWTH CHARACTERISTICS OF SOME UNICELLULAR} MARINE ALGAE AND OF CHLORELLA PYRENOIDOSA

\begin{tabular}{|c|c|c|c|c|}
\hline & & & & \\
\hline Species & Author & Conditions & $\begin{array}{c}\text { constant (log } \\
\text { units/day) }\end{array}$ & $\begin{array}{c}\text { Final } \\
\text { cells/ml }\end{array}$ \\
\hline $\begin{array}{l}\text { Phaeodactylum } \\
\text { tricornutum }\end{array}$ & Spencer, I954 & Laboratory culture & $\mathrm{I} \cdot 7\left(25^{\circ} \mathrm{C}\right)$ & - \\
\hline & $\begin{array}{l}\text { Raymont \& } \\
\text { Adams, I958 }\end{array}$ & Large-scale tanks & $0.69\left(13.5^{\circ}-18^{\circ} \mathrm{C}\right)$ & $3.2 \times 10^{7}$ \\
\hline $\begin{array}{l}\text { Chlorella } \mathrm{sp} . \\
\text { (marine) }\end{array}$ & Loosanoff, I95I & Large-scale tanks & - & $3.5 \times 10^{7}$ \\
\hline $\begin{array}{l}\text { Dunaliella } \\
\text { bioculata }\end{array}$ & Eddy, 1956 & Laboratory culture & $\begin{array}{l}\mathrm{I} \cdot \mathrm{I}\left(25^{\circ} \mathrm{C}\right) \\
\mathrm{I} \cdot 8\left(29^{\circ} \mathrm{C}\right) \\
2.9\left(33^{\circ} 5^{\circ} \mathrm{C}\right)\end{array}$ & $\begin{array}{l}2.5 \times 10^{7} \\
1 \cdot 2 \times 10^{7} \\
7.2 \times 10^{6}\end{array}$ \\
\hline $\begin{array}{l}\text { Asterionella } \\
\text { japonica }\end{array}$ & $\begin{array}{l}\text { Kain \& Fogg, } \\
\text { I958a }\end{array}$ & Laboratory culture & $\mathrm{I} \cdot 2\left(20-25^{\circ} \mathrm{C}\right)$ & $4.0 \times 10^{6}$ \\
\hline $\begin{array}{l}\text { Isochrysis } \\
\text { galbana }\end{array}$ & $\begin{array}{l}\text { Kain \& Fogg, } \\
\text { I958b }\end{array}$ & Laboratory culture & $0.55\left(20^{\circ} \mathrm{C}\right)$ & $2.4 \times 10^{7}$ \\
\hline $\begin{array}{l}\text { Prorocentrum } \\
\text { micans }\end{array}$ & This paper & Laboratory culture & $0.3\left(20^{\circ} \mathrm{C}\right)$ & $5.0 \times 10^{4}$ \\
\hline $\begin{array}{l}\text { Chlorella } \\
\text { pyrenoidosa }\end{array}$ & $\begin{array}{l}\text { Thacker \& } \\
\text { Babcock, I957 }\end{array}$ & $\begin{array}{l}\text { Large-scale con- } \\
\text { tinuous aseptic cu }\end{array}$ & ire $2.0\left(25^{\circ} \mathrm{C}\right)$ & $3.7 \times 10^{8}$ \\
\hline
\end{tabular}

more economic in certain circumstances. The general principles underlying the large-scale culture of algae have been considered in several publications (e.g. Tamiya, 1957; Thacker \& Babcock, 1957; Fogg, 1957) and here it is our intention only to comment briefly on such features of the organisms studied by us as seem important for their growth in large-scale cultures.

The maximum relative growth rates of Asterionella japonica, Isochrysis galbana and Prorocentrum micans are lower than those of other organisms which have been considered from this point of view (Table 7), but this is not necessarily of great importance since in mass culture the aim should be to achieve a linear phase of growth in which yield per unit time is proportional 
to the amount of light received. Here, there may be an advantage in using organisms such as Asterionella japonica and Prorocentrum micans which require relatively high intensities for saturation and which may thus give greater yields for a given amount of light. The maximum yield per unit volume of medium is of considerable importance for successful large-scale culture, since dense suspensions are necessary for economic handling. The maximum final cell concentration achieved in cultures of marine algae have so far been only about one-tenth of those achieved in ordinary large-scale cultures of Chlorella (Table 7) and even when differences in cell size are allowed for the yield per unit volume of the former remains poor by comparison. In our densest cultures nitrate, phosphate, salinity, hydrogen-ion concentration and carbon dioxide were not limiting and the nature of the factors determining the final population density is unknown; natural sea water with simple additions of nitrate and phosphate is not necessarily the medium giving maximum yields of these organisms and it may be that adjustment of ionic ratios, as has proved successful with the freshwater alga Monodus (Miller \& Fogg, 1957), or addition or removal of organic factors will be necessary to obtain worthwhile improvements in yield. Finally, it may be pointed out that harvesting is one of the most expensive processes in the mass culture of algae and that organisms such as Asterionella japonica and Prorocentrum micans, being considerably larger, are more readily separated from the culture medium than is Chlorella.

Part of this work was carried out under extra-mural contract with the Institute of Seaweed Research. We are grateful to the Institute for a maintenance grant made to one of us (J.M.K.). We are also very grateful for the technical assistance of Miss W. B. Chapman.

\section{SUMMARY}

The dinoflagellate Prorocentrum micans has been grown in bacteria-free, as well as uni-algal, culture under controlled conditions and its growth measured by means of cell counts.

The relative growth constant was about $0.3 \log _{e}$ units/day. Ranges of salinity of $20-40 \%$ and of $\mathrm{pH}$ of $7 \cdot 5-8 \cdot 75$ were tolerated. The optimum incandescent light intensity was 3000-39,000 lux (300-3900 $\left.\mu \mathrm{g}-\mathrm{cal} / \mathrm{cm}^{2} \mathrm{sec}\right)$. Fluorescent light of more than 2000 lux ( $150 \mu \mathrm{g}-\mathrm{cal} / \mathrm{cm}^{2} \mathrm{sec}$ ) was usually inhibitory, a phenomenon which may have been associated with phototaxis. The lag time decreased with increasing light intensity.

The provision of a suitable chelator seemed very important for this organism. Ethylenediamine tetra-acetic acid was fairly satifactory but glycylglycine was better. Its requirement for cobalamin was confirmed and it was also found to need biotin. Prolonged growth in a completely synthetic medium was not achieved. 
A final cell concentration of $50-80$ cells $/ \mathrm{mm}^{3}$ was obtained. The minimum nitrogen requirement was I9 $\mu \mu \mathrm{g}$-atoms $\mathrm{N} /$ cell and the minimum phosphorus requirement $0.94 \mu \mu \mathrm{g}$-atoms $\mathrm{P} /$ cell.

The results from the three organisms studied in this series are compared with those obtained by other workers.

\section{REFERENCES}

BACHRACH, E. \& LUCCIARDI, N., 1932. Influence de la concentration en ions hydrogène $(\mathrm{pH})$ sur la multiplication de quelques diatomées marines. Rev. algol., T. 6, pp. 25I-6r.

BARKER, H. A., I935. The culture and physiology of the marine dinoflagellates. Arch. Mikrobiol., Bd. 6, pp. 157-81.

BRAarud, T. \& RosSAvIK, E., I95I. Observations on the marine dinoflagellate Prorocentrum micans Ehrenb. in culture. Avh. norske VidenskAkad., I95I, No. I, pp. I-I8.

CHU, S. P., 1943. The influence of the mineral composition of the medium on the growth of planktonic algae. II. The influence of the concentration of inorganic nitrogen and phosphate phosphorus. F. Ecol., Vol. 31, pp. 109-48.

Droop, M. R., I954. A note on the isolation of small marine algae and flagellates for pure culture. F. mar. biol. Ass. U.K., Vol. 33, pp. 51 I-I4.

- 1957. Auxotrophy and organic compounds in the nutrition of marine phytoplankton. F. gen. Microbiol., Vol. I6, pp. 286-93.

- 1958. Requirement for thiamine among some marine and supra-littoral protista. F. mar. biol. Ass. U.K., Vol. 37, pp. 323-29.

EDDy, B. P., 1956. The suitability of some algae for mass cultivation for food, with special reference to Dunaliella bioculata. F. exp. Bot., Vol. 7, pp. 372-80.

FoGG, G. E., 1957. The microbiological production of foodstuffs. Rep. Progr. appl. Chem., Vol. 42, pp. 699-707.

- 1959. Nitrogen nutrition and the pattern of metabolism in algae. Symp. Soc. exp. Biol., Vol. 13, pp. 106-25.

FøYN, B., I934. Lebenscyclus, Cytologie und Sexualität der Chloriphycee Cladophora Suhriana Kützing. Arch. Protistenk., Bd. 83, p. I.

GoldBerg, E. D., Walker, T. J. \& Whisenand, A., I95I. Phosphate utilization by diatoms. Biol. Bull., Woods Hole, Vol. ror, pp. 274-84.

HaLldal, P., 1958. Action spectra of phototaxis and related problems in Volvocales, Ulva-gametes and Dinophyceae. Physiol. plant., Vol. II, pp. II8-53.

Haxo, F. T., \& SweEney, B. M., 1955. Bioluminescence in Gonyaulax polyedra. In The Luminescence of Biological Systems, ed. Johnson, F. H. Washington D.C.: Amer. Acad. Adv. Sci. pp. 415-20.

KAIN, J. M. \& FoGG, G. E., I958a. Studies on the growth of marine phytoplankton. I. Asterionella japonica Gran. F. mar. biol. Ass. U.K., Vol. 37, pp. 397-413.

- I958b. Studies on the growth of marine phytoplankton. II. Isochrysis galbana Parke. F. mar. biol. Ass. U.K., Vol. 37, pp. 781-88.

Ketchum, B. H., 1939a. The development and restoration of deficiencies in the phosphorus and nitrogen composition of unicellular plants. f. cell. comp. Physiol., Vol. 13, pp. 373-81.

- 1939 b. The absorption of phosphate and nitrate by illuminated cultures of Nitzschia closterium. Amer. F. Bot., Vol. 26, pp. 399-407. 
Loosanoff, V. L., 1951. Culturing phytoplankton on a large scale. Ecology, Vol. 32, pp. 748-50.

LUND, J. W. G., 1950. Studies on Asterionella formosa Hass. II. Nutrient depletion and the spring maximum. Part II. Discussion. F. Ecol., Vol. 38, pp. 15-35.

— I95I. A sedimentation technique for counting algae and other organisms. Hydrobiologia, Vol. 3, pp. 390-94.

MACKERETH, F. J., 1953. Phosphorus utilization by Asterionella formosa Hass. f. exp. Bot., Vol. 4, pp. 296-313.

MilleR, J. D. A. \& FoGG, G. E., 1957. Studies on the growth of Xanthophyceae in pure culture. I. The mineral nutrition of Monodus subterraneus Peterson. Arch. Mikrobiol. Vol. 28, pp. I-57.

MYERS, J., I946. Culture conditions and the development of the photosynthetic mechanism. III. Influence of light intensity on cellular characteristics of Chlorella. F. gen. Physiol., Vol. 29, pp. 419-27.

I951. Physiology of the algae. Annu. Rev. Microbiol., Vol. 5, pp. 157-80.

1953. Growth characteristics of algae in relation to the problems of mass culture. In Algal Culture from Laboratory to Pilot Plant, Carnegie Institution of Washington Publication no. 600, pp. 37-54.

NoRDLI, E., I957. Experimental studies on the ecology of Ceratia. Oikos, Vol. 8, pp. 200-65.

PRovasoli, L., I957. Alcune considerazioni sui caratteri morfologici e fisiologici delle alghe. Estratto dal Boll. Zool. agr. Bachic. Vol. 22, pp. I43-88.

I958a. Growth factors in unicellular marine algae. Perspectives in Marine Biology, edited by A. A. Buzzati-Traverso. University of California Press. pp. $385-503$.

- 1958b. Nutrition and ecology of protozoa and algae. Annu. Rev. Microbiol., Vol. 12, pp. 279-308.

Provasoli, L. \& Howell, J. F., I952. Culture of a marine Gyrodinium in a synthetic medium. Proc. Amer. Soc. Protozoologists, Vol. 3, p. 6.

Provasoli, L. \& McLaughiln, J. J. A. \& Droop, M. R., I957. The development of artificial media for marine algae. Arch. Mikrobiol., Bd. 25, pp. 392-428.

Provasoli, L., McLaughi IN, J. J. A. \& Pintner, I. J., I954. Relative and limiting concentrations of major mineral constituents for the growth of algal flagellates. Trans. N.Y. Acad. Sci. Vol. 16, pp. 412-17.

Raymont, J. E. G. \& AdAMS, M. N. E., 1958. Studies on the mass culture of Phaeodactylum. Limnolo. Oceanogr., Vol. 3, pp. II9-36.

RoDHE, W., 1948. Environmental requirements of freshwater plankton algae. Symb. bot. upsaliens., Vol. Io, pp. I-I 49 .

RYTHER, J. H., I954. The ecology of phytoplankton blooms in Moriches Bay and Great South Bay, Long Island, New York. Biol. Bull., Woods Hole, Vol. I06, pp. $198-209$.

SoRoKIN, C. \& KRAUSS, R. W., I958. The effects of light intensity on the growth rates of green algae. Plant Physiol., Vol. 33, pp. 109-13.

SPENCER, S. P., I954. Studies on the culture of a marine diatom. F. mar. biol. Ass. U.K., Vol. 33, pp. 265-90.

Tamrya, H., I957. Mass culture of algae. Annu. Rev. Plant Physiol., Vol. 8, pp. 309-34.

THACKER, D. R. \& BABCOCK, H., 1957. The mass culture of algae. F. solar Energy Sci. Engng, Vol. I, pp. 37-50. 